\title{
Correction to: A Research Note on the Convergence of Childlessness Rates Between Women with Secondary and Tertiary Education in the United States
}

\section{Anna Rybińska ${ }^{1}$}

Published online: 11 February 2020

(c) Springer Nature B.V. 2020

\section{Correction to: European Journal of Population}

\section{https://doi.org/10.1007/s10680-019-09550-z}

The original version of this article unfortunately contained a mistake. In the article published online 22 January 2020 figure 2 was printed without crucial value labels. In addition, on the same figures, the values which were included were misaligned. The correct Fig. 2 is published below.

The original article has been corrected.

The original article can be found online at https://doi.org/10.1007/s10680-019-09550-z.

Anna Rybińska

a.rybinska@duke.edu

1 Sanford School of Public Policy, Duke University, Duke Box 90539, Durham, NC 27708, USA 


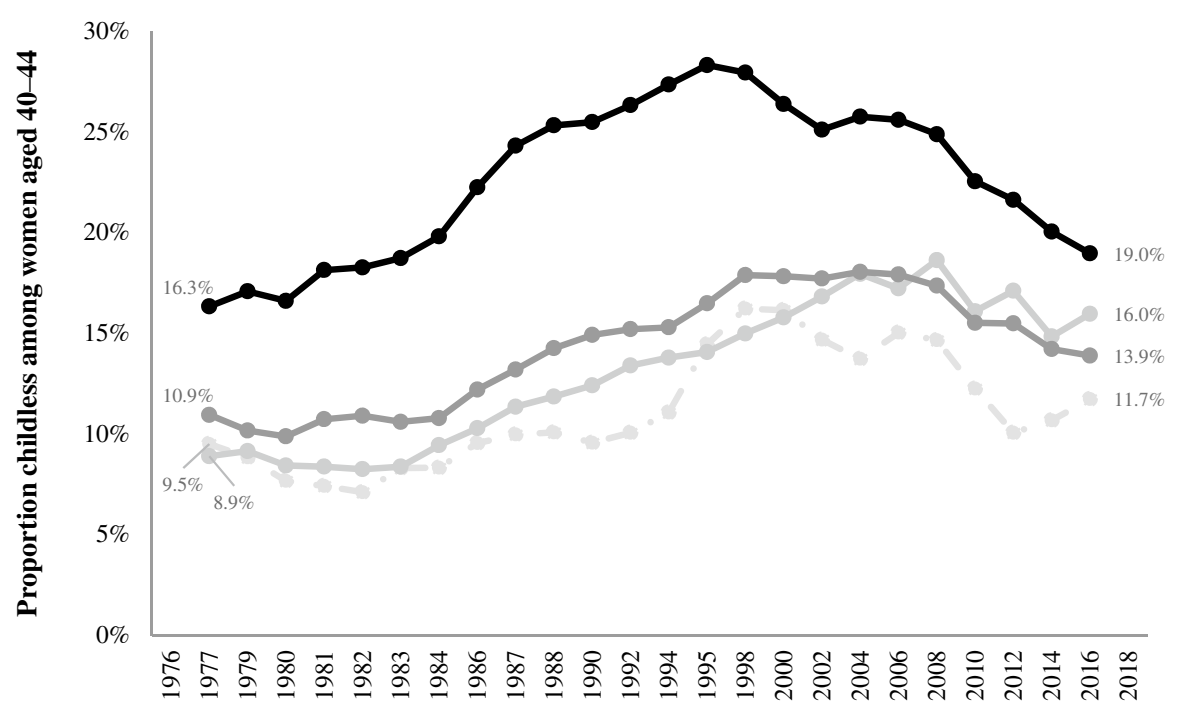

CPS Fertility Supplement Year

less than high school $\quad$ high school $\quad$ some college $\quad$ college

Fig. 2 Weighted proportions of non-Hispanic white women aged 40-44 in the United States who remain childless by year and educational category. Source: Current Population Survey June Fertility Supplement provided by IPUMS USA (Flood et al. 2018). Findings presented as an average of estimates across three subsequent waves

Publisher's Note Springer Nature remains neutral with regard to jurisdictional claims in published maps and institutional affiliations. 